\title{
A review of the brittle ice zone in polar ice cores
}

\author{
Peter D. NEFF \\ Antarctic Research Centre, Victoria University of Wellington, Wellington, New Zealand \\ E-mail: peter.neff@vuw.ac.nz \\ National Isotope Centre, GNS Science, Gracefield, New Zealand
}

\begin{abstract}
Maintaining ice-core quality through the brittle ice zone (BIZ) remains challenging for polar ice-core studies. At depth, increasing ice overburden pressurizes trapped air bubbles, causing fracture of cores upon exposure to atmospheric pressure. Fractured ice cores degrade analyses, reducing resolution and causing contamination. BIZ encounters at 18 sites across the Greenland, West and East Antarctic ice sheets are documented. The BIZ begins at a mean depth of $545 \pm 162 \mathrm{~m}$ (1 standard deviation), extending to depths where ductile clathrate ice is reached: an average of $1132 \pm 178 \mathrm{~m}$ depth. Ice ages in this zone vary with snow accumulation rate and ice thickness, beginning as young as $\mathbf{2} \mathrm{ka}$ BP at Dye-3, Greenland, affecting ice $>160 \mathrm{ka}$ BP in age at Taylor Dome, Antarctica, and compromising up to $90 \%$ of retrieved samples at intermediate-depth sites. Effects of pressure and temperature on the BIZ are explored using modeled firn-column overburden pressure and borehole temperatures, revealing complex associations between firn densification and BIZ depth, and qualitatively supporting expected thinning of the BIZ at low ice temperatures due to shallower clathrate stability. Mitigating techniques for drilling, transport, sampling and analysis of brittle ice cores are also discussed.
\end{abstract}

KEYWORDS: clathrate hydrates, ice core, ice coring, paleoclimate, polar firn

\section{INTRODUCTION}

Deep ice drilling at both poles reveals valuable climate records extending up to $800 \mathrm{ka}$ into the past (EPICA Community Members, 2004), in addition to unveiling much about the physical structure of the Greenland, West and East Antarctic ice sheets. In recent years, ice-core drilling, transport, sampling and analytical procedures have continually improved, spurred by the goal of providing continuous, high-resolution records of atmospheric greenhouse gases and climate and environmental proxies.

However, poor ice-core quality in the so-called brittle ice zone (BIZ), where extensive fracturing of core samples is caused by rapid relaxation (decompression) of the ice (e.g. Gow, 1971), remains a technical challenge at all phases of intermediate-depth and deep ice-core studies. At the drill site, mechanical stresses from drilling and logging the core can degrade initial core quality in this zone. Sampling at freezer facilities often induces further fracturing as individual brittle ice-core samples are cut with bandsaws. Finally, brittle ice samples prove challenging for laboratory procedures such as continuous-flow analysis (e.g. Osterberg and others, 2006; Bigler and others, 2011), with fractures allowing drilling fluid required for deep ice drilling to penetrate into samples, contaminating major-ion chemistry, trace chemistry and gas measurements.

While at relatively high-snow-accumulation deep drill sites ice ages in the BIZ represent several thousand years of the Holocene, high-snow-accumulation intermediate-depth drill sites and low-snow-accumulation deep drill sites may place many thousands of years of transitional and/or glacial ice within this zone of compromised core quality. In the case of drill sites with intermediate ice thickness, a large fraction $(90 \%$ or more) of the dated ice-core record will likely be placed within the BIZ. Brittle ice-core quality, through recovery, transport, sampling and analysis, is one of the technical challenges identified by the International
Partnerships in Ice Core Sciences (IPICS), with implications both for the '40k array' initiative to gather a spatially distributed, bipolar network of $40 \mathrm{ka}$ ice-core records, and any Antarctic 'oldest ice' site chosen to retrieve a continuous 1.5 Ma record (IPICS, 2005; Brook and others, 2006).

The term 'brittle ice' with respect to ice drilling originates in the description by Gow and others (1968) of highly fractured ice from depths between 400 and $900 \mathrm{~m}$ in the Byrd Station ice core, the first drilled to bedrock in Antarctica. Investigation of ice relaxation by Gow (1968, 1971), also in the Byrd Station ice core, indicates that the linear increase in overburden pressure with depth accordingly increases the in situ pressure within air bubbles in the ice; once removed from this high-pressure environment, bubble pressure exceeds the tensile strength of the confining ice, causing cracking between bubbles and initiating widespread fracturing in ice cores (Uchida and others, 1994; IPICS, 2005). Immediately upon exposure at the surface, fracturing begins explosively, propagating across- and alongcore on decimeter scales. Slower relaxation of ice cores over periods of months to years after drilling (also explored by Gow, 1971) may alleviate some or all remaining brittleness; however, ice cores from Siple Dome, Antarctica, remain brittle more than a decade after cores were retrieved (personal communication from M. Twickler, 2013). Brittle fracture in ice cores only fully diminishes at depths where air bubbles are absorbed into the ice, transitioning to air-hydrate crystals (clathrates). Here the ice is more ductile as dissociation pressure and temperature is reached, incorporating gases into the crystal lattice (e.g. Miller, 1969; Shoji and Langway, 1982; Pauer and others, 1995; Kuhs and others, 2000; Lipenkov, 2000). This transition occurs gradually as bubble number-densities decrease and clathrates become dominant (e.g. Uchida and others, 1994; Kipfstuhl and others, 2001; Ueltzhöffer and others, 2010). It is expected that clathrate formation, and thus onset of ductile 


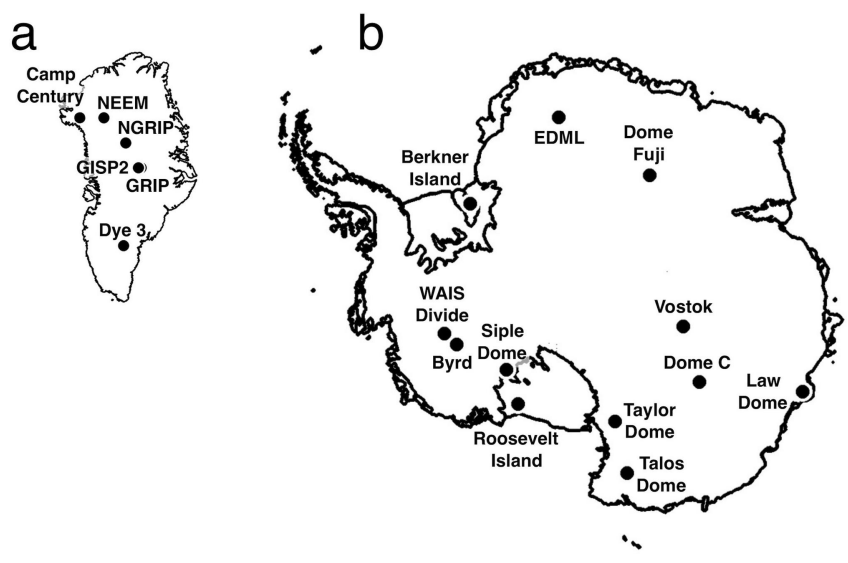

Fig. 1. Locations of polar drill sites in (a) Greenland and (b) Antarctica discussed in text. Map data from Timmermann and others (2010).

ice and improved ice-core quality, occurs at shallower depths as ice temperature decreases (Miller, 1969).

The BIZ, though observed at all deep drilling sites, has seldom been specifically examined and is only approximately defined as a zone beginning several hundred meters below the ice surface and extending to depths between 1000 and $1500 \mathrm{~m}$. This is in part due to the inherently qualitative definition of brittle ice, wide-ranging metrics for ice-core quality, rounding of reported depths, and the entangled effects of ice physical properties and stresses (mechanical and thermal) induced during drilling, on-site handling and transport. BIZ depths collated here are likely accurate to $\pm 50 \mathrm{~m}$. The first sustained decline in ice-core quality should be reported, and is considered here, as the top depth of the BIZ, with the bottom depth marked by a return to consistently excellent ice-core quality (e.g. fig. 10 of Souney and others, 2014). This paper compiles reported information regarding the BIZ for 18 deep (>1500 m) and intermediate-depth (500-1500 m) polar ice-drilling projects (Fig. 1a and b). Two effects are explored with possible controls on brittle ice onset and relief. First, the effect of varying firn-column thickness on overburden pressure at depth is considered using modeled firn-column densities at all sites. Second, reported brittle ice depths are examined with respect to clathrate stability using in situ ice temperature from borehole measurements and modeled overburden pressures. Techniques are detailed that have been or could be employed to reduce brittle fracture in ice cores during drilling, transport and sampling, and challenges pertaining to analysis of brittle ice samples are also discussed.

\section{BRITTLE ICE ZONE DEPTH}

Reported BIZ depths and drill site conditions - snow accumulation rate, mean annual surface air temperature and firn/ ice transition (FIT) depth - are summarized in Tables 1, 2 and 3 for sites across the Greenland ice sheet (GIS), West Antarctic ice sheet (WAIS) and East Antarctic ice sheet (EAIS), respectively. BIZ top and bottom depths, as well as FIT depth (assuming a density of $830 \mathrm{~kg} \mathrm{~m}^{-3}$ ), are displayed for all sites in Figure 2. While intermediate-depth drilling projects at Siple Dome, Berkner Island, Roosevelt Island, Law Dome and Taylor Dome experienced brittle ice conditions, the ice/ bed interface was encountered before reaching pressures and temperatures suitable for clathrate formation and the transition to ductile ice. Some ice-core quality improvement was anecdotally observed in the final several meters of the Siple Dome, Berkner Island and Roosevelt Island ice cores, possibly due to higher temperatures near the bed (Gow and Meese, 2007; Mulvaney and others, 2007; personal communication from N. Bertler, 2013).

\section{Pressure and temperature effects: brittle zone onset}

Snow accumulation rate and surface air temperature are primary controls on the densification of polar firn (e.g. Herron and Langway, 1980; Ligtenberg and others, 2011), although the firnification process is not fully understood (Hörhold and others, 2011). Firn densification is relevant here for its role in isolating air bubbles from porous firn and

Table 1. Site information, brittle ice zone (BIZ) depths (bold), mean annual snow accumulation, mean surface air temperature, firn/ice transition depth (density $830 \mathrm{~kg} \mathrm{~m}^{-3}$ reached) and BIZ ice ages for Greenland ice sheet ice-drilling sites. GRIP: Greenland Ice Core Project; GISP2: Greenland Ice Sheet Project 2; NGRIP: North Greenland Ice Core Project; NEEM: North Greenland Eemian Ice Drilling

\begin{tabular}{|c|c|c|c|c|c|c|}
\hline & Camp Century & Dye-3 & GRIP & GISP2 & NGRIP & NEEM \\
\hline Coordinates & $\begin{array}{l}77.17^{\circ} \mathrm{N} \\
61.13^{\circ} \mathrm{W}\end{array}$ & $\begin{array}{l}65.18^{\circ} \mathrm{N} \\
43.82^{\circ} \mathrm{W}\end{array}$ & $\begin{array}{l}72.58^{\circ} \mathrm{N} \\
37.63^{\circ} \mathrm{W}\end{array}$ & $\begin{array}{l}72.60^{\circ} \mathrm{N} \\
38.50^{\circ} \mathrm{W}\end{array}$ & $\begin{array}{l}75.10^{\circ} \mathrm{N} \\
42.32^{\circ} \mathrm{W}\end{array}$ & $\begin{array}{l}77.45^{\circ} \mathrm{N} \\
51.60^{\circ} \mathrm{W}\end{array}$ \\
\hline Years drilled & $1963-66^{1}$ & $1979-81^{7}$ & $1989-92^{9}$ & $1989-93^{14}$ & $1996-2004^{9}$ & $2008-12^{19}$ \\
\hline Surface elevation (m) & $1887^{2}$ & $2490^{7}$ & $3238^{11}$ & $3200^{14}$ & $2917^{9}$ & $2450^{19}$ \\
\hline Drill depth $(\mathrm{m})$ & $1387^{1}$ & $2037^{7}$ & $3029^{11}$ & $3053^{14}$ & $3090^{9}$ & $2540^{19}$ \\
\hline $\mathrm{BIZ}$ top $(\mathrm{m})$ & $600^{3}$ & $\mathbf{8 0 0}^{8,9}$ & $800^{11}$ & $\mathbf{6 5 0}^{15,16}$ & $790^{9}$ & $\mathbf{6 0 9}^{20}$ \\
\hline BIZ bottom $(\mathrm{m})$ & $1150^{3}$ & $1200^{8,9}$ & $1300^{11,12}$ & $1400^{15,16}$ & $1200^{9}$ & $1281^{20}$ \\
\hline BIZ thickness (m) & 550 & 400 & 500 & 750 & 410 & 671 \\
\hline Snow accumulation (m ice $\mathrm{a}^{-1}$ ) & $0.33^{2}$ & $0.56^{9}$ & $0.23^{9}$ & $0.22^{9}$ & $0.19^{9}$ & $0.22^{19}$ \\
\hline Mean air temperature $\left({ }^{\circ} \mathrm{C}\right)$ & $-24^{4}$ & $-20^{9}$ & $-32^{9}$ & $-32^{4}$ & $-32^{9}$ & $-29^{19}$ \\
\hline Firn/ice transition $(\mathrm{m})$ & $72^{5}$ & $67.5^{4}$ & $78^{13}$ & $77^{4}$ & $78^{18}$ & $78.8^{21}$ \\
\hline BIZ top age (ka BP) & $2.3^{6}$ & $2^{10}$ & $4^{9}$ & $3^{15,17}$ & $4.7^{9}$ & $3^{22}$ \\
\hline BIZ bottom age (ka BP) & $10^{6}$ & $3.8^{10}$ & $7.1^{9}$ & $8.3^{15,17}$ & $8^{9}$ & $9^{22}$ \\
\hline
\end{tabular}

${ }^{1}$ Ueda and Garfield (1968); ${ }^{2}$ Drinkwater and others (2001); ${ }^{3}$ Shoji and Langway (1987); ${ }^{4}$ Cuffey and Paterson (2010); ${ }^{5}$ Kovacs and others (1969); ${ }^{6}$ Dansgaard and others (1969); ${ }^{7}$ Gundestrup and Hansen (1984); ${ }^{8}$ Shoji and Langway (1982); ${ }^{9}$ Vinther and others (2006); ${ }^{10}$ Langway and others (1985); ${ }^{11}$ Dansgaard and others (1993); ${ }^{12}$ Pauer and others (1995); ${ }^{13}$ Schwander and others (1993); ${ }^{14}$ Alley and others (1993); ${ }^{15}$ Gow and others (1997); ${ }^{16} \mathrm{M}$. Twickler (personal communication, 2013); ${ }^{17}$ The Greenland Summit Ice Cores CD-ROM (1997); ${ }^{18}$ Martinerie and others (2009); ${ }^{19}$ NEEM Community Members (2013); ${ }^{20}$ Warming and others (2013); ${ }^{21}$ Buizert and others (2012); ${ }^{22}$ Rasmussen and others (2013). 


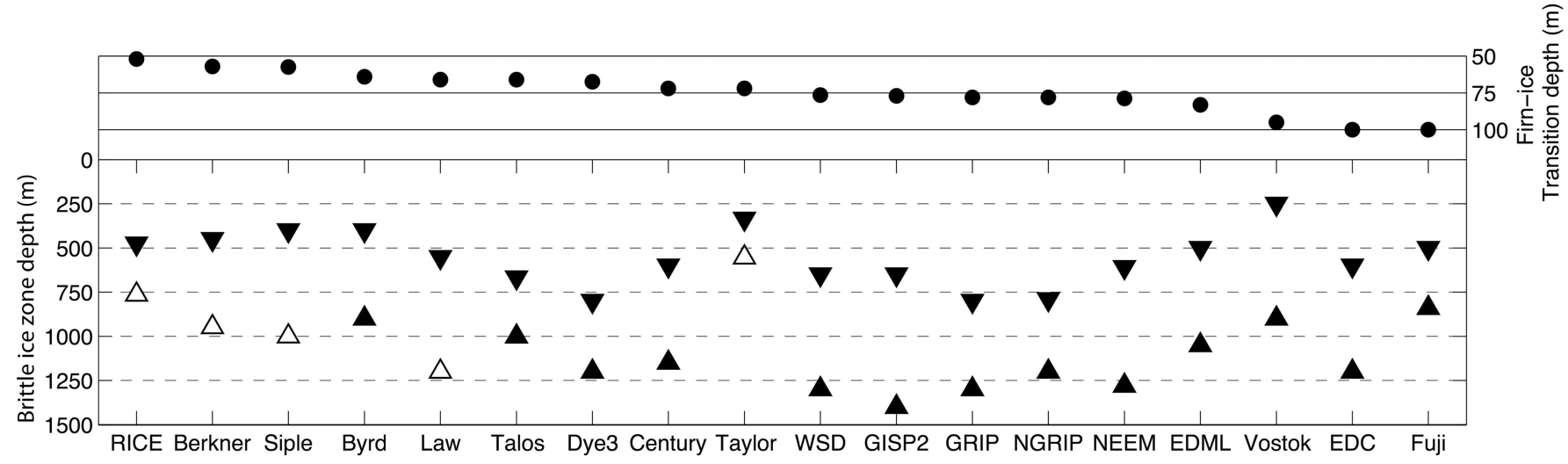

Fig. 2. Firn/ice transition (FIT; depth where density $830 \mathrm{~kg} \mathrm{~m}^{-3}$ reached; circles), BIZ top depths (inverted triangles) and BIZ bottom depths (triangles) at ice-drilling sites, ordered by increasing FIT depth. Open triangles denote BIZ bottom depths which represent the ice/bed interface, rather than transition to the bubble-free, ductile ice zone. RICE: Roosevelt Island Climate Evolution; WSD: WAIS Divide; GISP2: Greenland Ice Sheet Project 2; GRIP: Greenland Ice Core Project; NGRIP: North Greenland Ice Core Project; NEEM: North Greenland Eemian Ice Drilling; EDML: EPICA Dronning Maud Land; EDC: EPICA Dome C.

because the thickness and density of the firn column controls the exact overburden pressure imposed on ice and air bubbles at depth. Overburden pressure may affect where brittle fracture of ice cores commences, as thin firn columns at warmer, higher-snow-accumulation sites should reach full ice density $\left(920 \mathrm{~kg} \mathrm{~m}^{-3}\right)$ more rapidly and thus exert more overburden pressure on ice and air bubbles at depth, and vice versa. Additionally, overburden pressure and in situ ice temperature control clathrate stability and are expected to affect the depth of the transition out of the bubbly BIZ and into the bubble-free, ductile clathrate-ice zone below, with clathrates stabilizing at lower (higher) pressures when temperatures are low (high) (e.g. Miller, 1969).

To quantify the influence of firn column thickness on overburden pressure at depth, while also converting BIZ depths to equivalent overburden pressures, firn-column density is modeled using the University of Washington Firn Model Intercomparison Experiment online Herron and Langway (1980) model (FirnMICE, http://firny.ess.washington. edu/communityfirnmodel/). A surface snow density of $390 \mathrm{~kg} \mathrm{~m}^{-3}$ is assumed for all sites, and mean annual surface air temperature and snow accumulation rate (ice equivalent) are input into the model to construct $1 \mathrm{~m}$ resolution depthdensity profiles from the surface to $300 \mathrm{~m}$ for each site (Fig. 3a). Constant ice density of $920 \mathrm{~kg} \mathrm{~m}^{-3}$ is assumed below $300 \mathrm{~m}$, although for bubbly ice this may be an overestimate of several $\mathrm{kg} \mathrm{m}^{-3}$. Snow density measurements from Taylor Dome, Berkner Island and WAIS Divide agree well with model data generated for these sites (density measurements provided with the FirnMICE online model, not shown). Overburden pressure at a given depth is calculated as the sum of overlying snow and ice with density prescribed by the FirnMICE model output. One cubic meter of ice (density $920 \mathrm{~kg} \mathrm{~m}^{-3}$ ) exerts $9.02 \times 10^{-3} \mathrm{MPa}$ overburden pressure (Fig. 3b). Modeled overburden pressure at $300 \mathrm{~m}$, the depth at which the thickest modeled firn column (Dome Fuji) reaches ice density of $920 \mathrm{~kg} \mathrm{~m}^{-3}$, is presented in Figure $3 \mathrm{c}$ for all sites, plotted against modeled and observed FIT depths $\left(830 \mathrm{~kg} \mathrm{~m}^{-3}\right.$ density). The mean misfit between observed and modeled FIT depth is $-4 \%$, with minimum misfits of $+1 \%$ and $-2 \%$ (EPICA Dome $C$ and WAIS Divide, respectively) and a maximum misfit of $-25 \%$ (Siple Dome).

Table 2. Site information, BIZ depths (bold), mean annual snow accumulation, mean surface air temperature, FIT depth (density $830 \mathrm{~kg} \mathrm{~m}^{-3}$ reached) and BIZ ice ages for WAIS ice-drilling sites

\begin{tabular}{|c|c|c|c|c|c|}
\hline & Byrd Station & Siple Dome & Berkner Island & WAIS Divide & Roosevelt Island \\
\hline Coordinates & $80.02^{\circ} \mathrm{S}, 119.52^{\circ} \mathrm{W}$ & $81.65^{\circ} \mathrm{S}, 148.81^{\circ} \mathrm{W}$ & $79.55^{\circ} \mathrm{S}, 45.68^{\circ} \mathrm{W}$ & $79.47^{\circ} \mathrm{S}, 112.09^{\circ} \mathrm{W}$ & $79.36^{\circ} \mathrm{S}, 161.71^{\circ} \mathrm{W}$ \\
\hline Years drilled & $1966-68^{1}$ & $1997-99^{5}$ & $2003-05^{7}$ & $2006-11^{10}$ & 2011-12 \\
\hline Surface elevation (m) & $1530^{1}$ & $620^{5}$ & $890^{7}$ & $1766^{10}$ & 550 \\
\hline Drill depth (m) & $2164^{1}$ & $1004^{5}$ & $948^{7}$ & $3405^{10}$ & 764 \\
\hline Ice thickness (m) & $2164^{1}$ & $1004^{5}$ & $948^{7}$ & $3455^{10}$ & 764 \\
\hline BIZ bottom $(\mathrm{m})$ & $900^{1,2}$ & $1000^{5}$ & $948^{7}$ & $1300^{11}$ & 764 \\
\hline BIZ thickness (m) & 500 & 600 & 498 & 650 & 289 \\
\hline Snow accumulation (m ice $\mathrm{a}^{-1}$ ) & $0.14^{3}$ & $0.11^{3}$ & $0.13^{7}$ & $0.22^{10}$ & $0.23^{13}$ \\
\hline Mean air temperature $\left({ }^{\circ} \mathrm{C}\right)$ & $-28^{3}$ & $-25^{3}$ & $-26.5^{7}$ & $-30^{10}$ & $-23^{13}$ \\
\hline Firn/ice transition $(\mathrm{m})$ & $64^{3}$ & $57.5^{3}$ & $57^{8}$ & $76.5^{12}$ & $52^{13}$ \\
\hline BIZ top age (ka BP) & $3.5^{4}$ & $5^{6}$ & $4.5^{9}$ & $2.7^{10}$ & $4^{13}$ \\
\hline BIZ bottom age (ka BP) & $9.5^{4}$ & $57^{6}$ & $95^{9}$ & $6^{10}$ & $>40^{13}$ \\
\hline
\end{tabular}

${ }^{1}$ Gow (1968); ${ }^{2}$ Gow (1971); ${ }^{3}$ Cuffey and Paterson (2010); ${ }^{4}$ Blunier and Brook (2001); ${ }^{5}$ Gow and Meese (2007); ${ }^{6}$ Brook and others (2005); ${ }^{7}$ Mulvaney and others (2007); ${ }^{8}$ Gerland and others (1999); ${ }^{9}$ R. Mulvaney (personal communication (2014); ${ }^{10}$ WAIS Divide Project Members (2013); ${ }^{11}$ Souney and others (2014); ${ }^{12}$ Kreutz and others (2011); ${ }^{13}$ N. Bertler (unpublished information). 
Table 3. Site information, BIZ depths (bold), mean annual snow accumulation, mean surface air temperature, FIT depth (density $830 \mathrm{~kg} \mathrm{~m}^{-3}$ reached) and BIZ ice ages for EAIS ice-drilling sites

Law Dome Taylor Dome Vostok station EPICA Dome C Dome Fuji EPICA Dronning Talos Dome Maud Land

\begin{tabular}{|c|c|c|c|c|c|c|c|}
\hline Coordinates & $\begin{array}{l}66.77^{\circ} \mathrm{S} \\
112.80^{\circ} \mathrm{E}\end{array}$ & $\begin{array}{l}77.70^{\circ} \mathrm{S} \\
159.07^{\circ} \mathrm{E}\end{array}$ & $\begin{array}{l}78.47^{\circ} \mathrm{S} \\
106.87^{\circ} \mathrm{E}\end{array}$ & $\begin{array}{l}75.10^{\circ} \mathrm{S} \\
123.35^{\circ} \mathrm{E}\end{array}$ & $\begin{array}{l}77.32^{\circ} \mathrm{S} \\
39.70^{\circ} \mathrm{E}\end{array}$ & $75^{\circ} \mathrm{S}, 0^{\circ} \mathrm{E}$ & $\begin{array}{l}72.78^{\circ} \mathrm{S} \\
159.07^{\circ} \mathrm{E}\end{array}$ \\
\hline Years drilled & $1991-93^{1}$ & $1993-94^{4}$ & $\begin{array}{l}1990-98 \\
2005-12^{7}\end{array}$ & $1999-2004^{12}$ & $\begin{array}{l}1993-96,{ }^{15} \\
2003-07^{16}\end{array}$ & $2000-06^{20}$ & $2005-07^{25}$ \\
\hline Surface elevation (m) & $1370^{1}$ & $2375^{5}$ & $3488^{8}$ & $3233^{13}$ & $3810^{15}$ & $2892^{21}$ & $2318^{26}$ \\
\hline Drill depth $(\mathrm{m})$ & $1200^{1}$ & $554^{4}$ & $3769^{9}$ & $3260^{12}$ & $3035^{16}$ & $2774^{20}$ & $1620^{26}$ \\
\hline Ice thickness (m) & $1220^{1}$ & $554^{4}$ & $3769^{9}$ & $3275^{12}$ & $3035^{16}$ & $2774^{20}$ & $1795^{26}$ \\
\hline $\mathrm{BIZ}$ top $(\mathrm{m})$ & $552^{2}$ & $335^{4}$ & $\mathbf{2 5 0} \mathbf{0}^{10}$ & $600^{14}$ & $500^{17}$ & $\mathbf{5 0 0}^{22}$ & $667^{27,28}$ \\
\hline BIZ thickness (m) & 648 & 291 & 650 & 600 & 340 & 550 & 334 \\
\hline Snow accumulation (m ice $\mathrm{a}^{-1}$ ) & $0.7^{1}$ & $0.06^{5}$ & $0.022^{11}$ & $0.036^{11}$ & $0.03^{15}$ & $0.064^{21}$ & $0.08^{26}$ \\
\hline Mean air temperature $\left({ }^{\circ} \mathrm{C}\right)$ & $-22^{1}$ & $-43^{5}$ & $-55^{8}$ & $-54^{11}$ & $-58^{15}$ & $-44^{21}$ & $-41^{26}$ \\
\hline Firn/ice transition $(\mathrm{m})$ & $66^{3}$ & $72^{4}$ & $95^{11}$ & $100^{11}$ & $100^{18}$ & $83^{23}$ & $66^{27}$ \\
\hline BIZ top age (ka BP) & $0.9^{1}$ & $10^{6}$ & $10.5^{8}$ & $29^{13}$ & $19.3^{19}$ & $7.7^{24}$ & $11^{26}$ \\
\hline BIZ bottom age (ka BP) & $20^{1}$ & $>160^{6}$ & $61.5^{8}$ & $80.5^{13}$ & $46^{19}$ & $24.3^{24}$ & $30^{26}$ \\
\hline
\end{tabular}

${ }^{1}$ Morgan and others (1997); ${ }^{2}$ Morgan and others (1994); ${ }^{3}$ Etheridge and others (1996); ${ }^{4}$ Fitzpatrick (1994); ${ }^{5}$ Morse and others $(1999) ;{ }^{6}$ Steig and others (2000); ${ }^{7}$ Vasiliev and others (2011); ${ }^{8}$ Petit and others (1999); ${ }^{9}$ Jouzel (2013); ${ }^{10}$ Uchida and others (1994); ${ }^{11}$ Cuffey and Paterson (2010); ${ }^{12}$ Parrenin and others (2007); ${ }^{13}$ EPICA Community Members (2004); ${ }^{14}$ Parrenin and others (2012); ${ }^{15}$ Watanabe and others (1999); ${ }^{16}$ Motoyama (2007); ${ }^{17}$ Fujii and others (2002); ${ }^{18}$ Hondoh and others (1999); ${ }^{19}$ Kawamura and others (2007); ${ }^{20}$ Severi and others (2007); ${ }^{21}$ Ueltzhöffer and others (2010); ${ }^{22} \mathrm{~F}$. Wilhelms (personal communication, 2014); ${ }^{23}$ Oerter and others (2004); ${ }^{24}$ EPICA Community Members (2010); ${ }^{25}$ TALDICE (Talos Dome Site Information; http://www.taldice.org/project/site/index. php); ${ }^{26}$ Stenni and others (2011); ${ }^{27}$ TALDICE, 2006/07 field season (http://www.taldice.org/site/0607/index.php); ${ }^{28}$ Schilt and others (2010); ${ }^{29}$ Frezzotti and others (2004)

Across the 18 drill sites, $300 \mathrm{~m}$ overburden pressure varies from $2.36 \mathrm{MPa}$ at Dome Fuji (modeled FIT depth $114 \mathrm{~m},+12 \%$ misfit) to $2.56 \mathrm{MPa}$ at Siple Dome (modeled FIT depth 46 m, $-25 \%$ misfit; Fig. 3b and c). Poor FIT depth reproduction for these end-member sites (Fig. 3c) suggests an overestimate of the possible range of overburden pressures; more conservative is $2.4 \mathrm{MPa}$ at EPICA Dome C (modeled FIT depth $101 \mathrm{~m},+1 \%$ misfit) to $2.55 \mathrm{MPa}$ at Berkner Island (modeled FIT depth $52 \mathrm{~m},-10 \%$ misfit). This overburden pressure fluctuation at depth, a maximum difference of $\sim 0.15-0.2 \mathrm{MPa}$ between the thickest firn column (slower firnification, lower overburden pressure at depth) and the thinnest (faster firnification, higher overburden pressure at depth), is equivalent to $16.5-22.2 \mathrm{~m}$ of ice overburden. If the firn column is ignored and full ice density is assumed from the surface, overburden pressure at depth $(2.7 \mathrm{MPa}$ at $300 \mathrm{~m})$ is overestimated by 0.14 $0.34 \mathrm{MPa}$ or $\sim 15.5-37.7 \mathrm{~m}$ of ice (dashed line, Fig. 3a and $b$ ). This results in an underestimation of the depth for theoretical clathrate stability. The BIZ does generally occur at shallower depths where the firn/ice transition is shallower (e.g. Fig. 2) and exerts greater overburden pressure at depth. This is most clearly observed at GIS and WAIS drill sites, although with low significance, as is expected due to low precision of reported BIZ depths and complex temperature and accumulation effects on firnification and clathrate formation processes. Reported BIZ top depths begin $\sim 10 \mathrm{~m}$ deeper per $1 \mathrm{~m}$ thickening of the FIT at the $11 \mathrm{GIS}$ and WAIS drill sites (regression of GIS and WAIS FIT depths and BIZ top depths gives $R^{2}=0.54$, not shown). As overburden pressure alone cannot explain such a deepening, this suggests that unidentified firnification processes likely exert significant control on BIZ onset depth. Proportional deepening of $\mathrm{BIZ}$ onset is not observed at all EAIS drill sites, especially not those on the EAIS plateau, perhaps because of increasing tensile strength of ice at smaller grain sizes and lower temperatures (e.g. Butkovich, 1954; Petrovich, 2003), as well as other unknown effects associated with extreme low-temperature and low-accumulation firn densification, grain growth and air-bubble formation.

\section{Pressure and temperature effects: brittle zone relief}

In situ ice temperature determines the depth (pressure) of clathrate stability and thus should affect the depth of the transition from bubbly, brittle ice to bubble-free, ductile ice. This is supported by observations of shallower appearance of clathrates and disappearance of air bubbles in ice cores at low-temperature sites (e.g. observations from Dye-3 and GRIP versus Vostok and Dome Fuji; Ikeda-Fukazawa and others, 2001). While temperature effects controlling BIZ onset are less clear, it is expected that the BIZ will be relieved at shallower depths (lower pressures) where ice temperatures are lower. Using overburden pressure as calculated above, and borehole temperature data from selected drill sites (Table 4), the BIZ can be evaluated with respect to temperature and pressure and thus compared more accurately with theoretical clathrate stability (Fig. 4). BIZ onset in many cases begins at pressures (depths) where clathrates should already begin to stabilize, but brittle fracture is not relieved until ductile conditions are reached as bubble number densities become sufficiently low and clathrates dominate, strengthening ice cores. While it is tempting to suggest that BIZ bottom pressure indeed decreases with lower ice temperatures, this is not a statistically significant feature including all reported BIZ data (excluding intermediate-depth sites where clathrates do not stabilize before the ice/bed interface is reached). Certainly the BIZ in the Greenland summit ice cores and at WAIS Divide (1200$1400 \mathrm{~m} \mathrm{BIZ}$ bottom depths; 10.5-12.5 MPa) extends several hundred meters deeper than that of Dome Fuji, Vostok, EPICA Dronning Maud Land and Talos Dome (840-1050 m BIZ bottom depths, 7.2-9.2 MPa), but the EPICA Dome $\mathrm{C}$ ice 

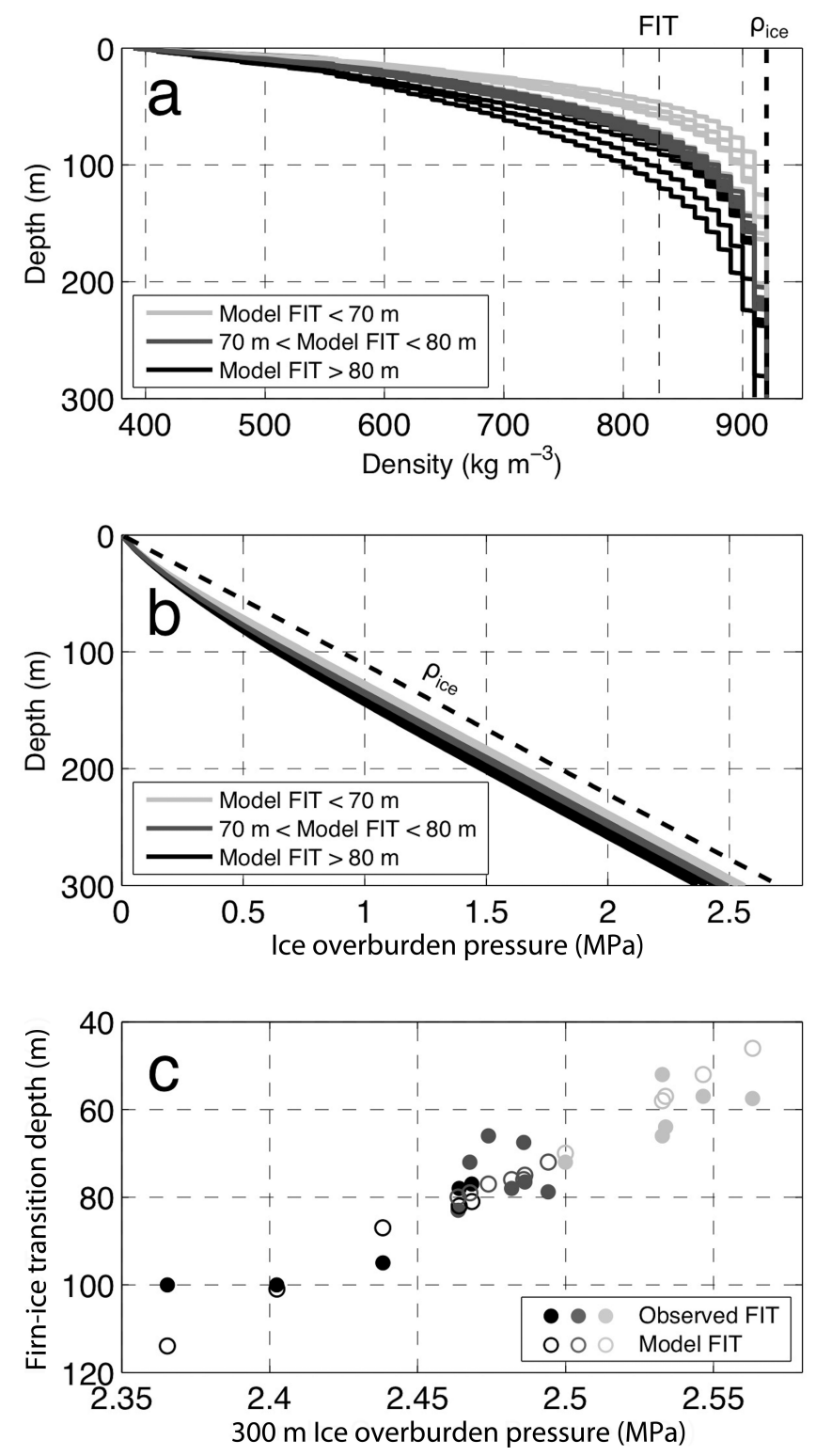

Fig. 3. Results of FirnMICE firn column density modeling (Herron and Langway (1980) model) and overburden pressure calculations. (a) Density-depth profiles generated for the 18 drill-site temperature and snow accumulation regimes, shaded according to modeled FIT depth (light grey: model FIT $<70 \mathrm{~m}$; grey: $70 \mathrm{~m}<$ model FIT $<80 \mathrm{~m}$; black: model FIT $>80 \mathrm{~m}$ ); bold dashed line indicates ice density $\left(920 \mathrm{~kg} \mathrm{~m}^{-3}\right)$. (b) Ice overburden pressure versus depth in the firn column $(0-300 \mathrm{~m})$ for the 18 drill sites (light grey: model FIT $<70 \mathrm{~m}$; grey: $70 \mathrm{~m}<$ model FIT $<80 \mathrm{~m}$; black: model FIT $>80 \mathrm{~m}$ ); bold dashed line indicates overburden pressure assuming constant ice density from the surface. (c) $300 \mathrm{~m}$ depth overburden pressure versus FIT depth from modeled (open circles) and measured (filled circles) firn-column density data.

core remained highly fractured to $1200 \mathrm{~m}$ depth $(10.5 \mathrm{MPa})$. Additionally, the BIZ at Camp Century, Dye-3 and Byrd Station transitions to ductile ice at shallow depths, with pressures only 1-2 MPa greater than that required for initial clathrate stability, while most sites transition out of the BIZ at pressures 3-5 MPa in excess of requirements for theoretical onset of clathrate stability (Fig. 4). This raises the interesting prospect that ice-flow advection of cold ice towards the surface at flank sites could encourage shallower formation of clathrates (e.g. Camp Century, Byrd Station; Shoji and Langway, 1987). However, without disentangling the effects

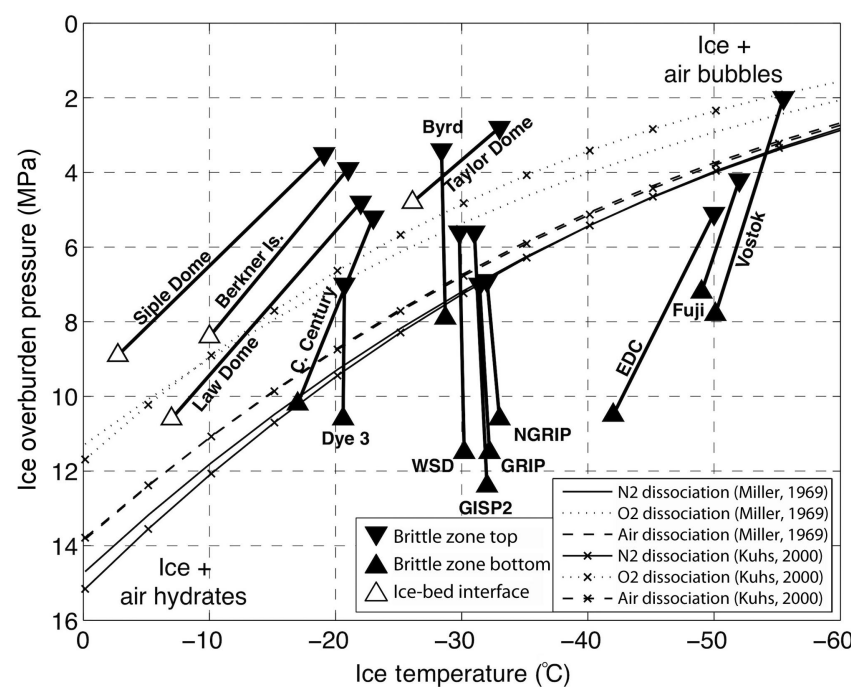

Fig. 4. BIZ top (inverted triangles) and bottom pressures (triangles) plotted at respective in situ ice temperature from borehole temperature measurements (Table 4). Theoretical clathrate stability curves are plotted for $\mathrm{N}_{2}$ (solid), $\mathrm{O}_{2}$ (dotted) and air (dashed) hydrates (Miller, 1969; Kuhs and others, 2000). The stability curve of Kuhs and others (2000) is indicated with ' $x$ '. Open triangles denote BIZ bottom pressures at the ice/bed interface, thus not the full transition from the bubbly, brittle-ice zone to the bubble-free, ductile ice zone below. WSD: WAIS Divide; EDC: EPICA Dome C.

Table 4. In situ ice temperature (borehole temperature; ${ }^{\circ} \mathrm{C}$ ) at $\mathrm{BIZ}$ top and bottom depths (see Tables 1-3) for selected sites. Temperatures are $\pm 0.5^{\circ} \mathrm{C}$, estimated from published graphical data where original datasets could not be accessed. Temperature data for Berkner Island are modeled

\begin{tabular}{|c|c|c|}
\hline Drill site & Temperature & Source \\
\hline & $\begin{array}{cc}\text { BIZ } & \text { BIZ } \\
\text { top depth } & \text { bottom depth }\end{array}$ & \\
\hline
\end{tabular}

\begin{tabular}{|c|c|c|c|}
\hline Camp Century & -23 & -17 & Shoji and Langway (1987) \\
\hline Dye-3 & -20.7 & -20.6 & Shoji and Langway (1987) \\
\hline GRIP & -31.4 & -32.2 & $\begin{array}{c}\text { The Greenland Summit Ice } \\
\text { Cores CD-ROM (1997) }\end{array}$ \\
\hline GISP2 & -31 & -32 & $\begin{array}{c}\text { The Greenland Summit Ice } \\
\text { Cores CD-ROM (1997) }\end{array}$ \\
\hline NorthGRIP & -32 & -33 & $\begin{array}{l}\text { Dahl-Jensen and others } \\
\text { (2003) }\end{array}$ \\
\hline Byrd Station & -28.4 & -28.7 & $\begin{array}{l}\text { Ueda and Garfield (1969), } \\
\text { T.J. Fudge (personal } \\
\text { communication, 2014) }\end{array}$ \\
\hline Siple Dome & -19.1 & -2.75 & $\begin{array}{l}\text { G. Clow (personal } \\
\text { communication }(2014)\end{array}$ \\
\hline Berkner Island & -21 & -10 & $\begin{array}{l}\text { Mulvaney and others } \\
\text { (2007) }\end{array}$ \\
\hline WAIS Divide & -29.8 & -30.2 & Cuffey and Clow (2014) \\
\hline Law Dome & -22 & -7 & $\begin{array}{l}\text { Van Ommen and others } \\
\text { (1999) }\end{array}$ \\
\hline Taylor Dome & -33 & -26.1 & $\begin{array}{c}\text { G. Clow (personal } \\
\text { communication, 2014) }\end{array}$ \\
\hline Vostok station & -55.5 & -50.1 & $\begin{array}{c}\text { Salamatin and others } \\
\text { (1994) }\end{array}$ \\
\hline EPICA Dome C & -50 & -42 & Pol and others (2010) \\
\hline Dome Fuji & -52 & -49 & $\begin{array}{l}\text { Ikeda-Fukuzawa and } \\
\text { others (2001) }\end{array}$ \\
\hline
\end{tabular}




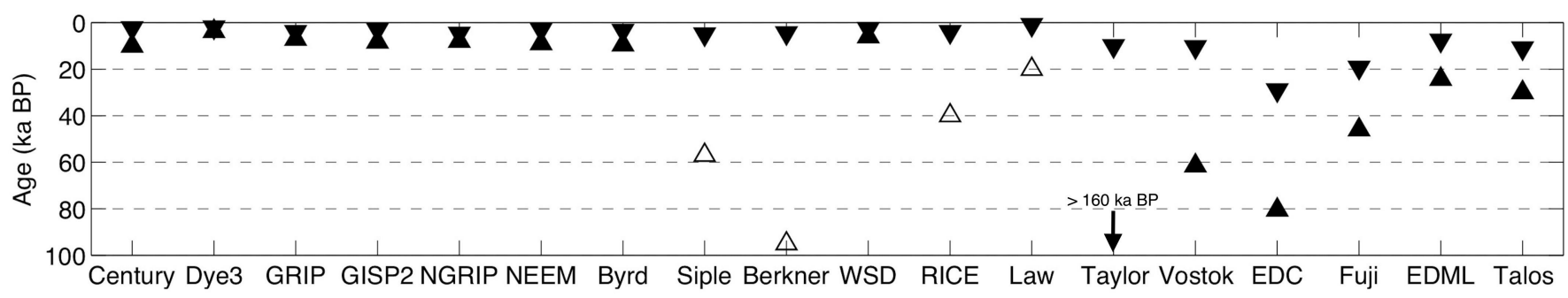

Fig. 5. BIZ top (inverted triangles) and bottom (triangles) age (ka BP) at drill sites, ordered by region and date of drilling. Open triangles denote BIZ bottom ages which represent the maximum dated age ( ice/bed interface) at these sites. WSD: WAIS Divide; RICE: Roosevelt Island Climate Evolution; EDC: EPICA Dome C; EDML: EPICA Dronning Maud Land.

of imprecise BIZ records, drill performance and ice-core handling/transport, it is difficult to use reported brittle ice depths to further evaluate this correlation between clathrate stability and the bottom of the BIZ.

To improve understanding of the mechanisms involved in $\mathrm{BIZ}$ onset and relief, it may prove useful to investigate ice physical properties including bubble number density, bubble size, micro-bubbles and ice fabric (e.g. grain size, crystal anisotropy). Take the anomalously shallow BIZ at Vostok, for example: Uchida and others (1994) observed a reduction of core quality caused by fractures as shallow as $100 \mathrm{~m}$ (likely linked to thermal drilling at Vostok), becoming heavily fractured from 250 to $750 \mathrm{~m}$ with progressive improvement to $900 \mathrm{~m}$ where core quality again became excellent. This shallowest occurrence of the BIZ may be related to a rapid increase in bubble number density (bubbles $\mathrm{cm}^{-3}$ ) observed in the Vostok ice core beginning at $\sim 300 \mathrm{~m}$ depth (increasing from $\sim 400$ to $\sim 800$ bubbles $\mathrm{cm}^{-3}$; Uchida and others, 1994; Ueltzhöffer and others, 2010). Such an increase in bubble number density may effectively reduce bubble pressures required for fracture propagation by narrowing interstitial ice between bubble cavities. Bubble number densities reported in the BIZ at Byrd Station and WAIS Divide were relatively more constant at $\sim 200$ and $\sim 450$ bubbles $\mathrm{cm}^{-3}$, respectively (Gow, 1971; Fitzpatrick and others, in press). Micro-bubbles formed through sublimation-condensation processes may also play a role at Vostok (e.g. Lipenkov, 2000), and are observed in the EPICA Dome C and Dronning Maud Land ice cores (Ueltzhöffer and others, 2010). The second shallowest occurrence of the $\mathrm{BIZ}, 335 \mathrm{~m}$ at Taylor Dome, may be anomalously shallow due to high strain rates at this site; elongated bubbles were observed from 360 to 390 m (Fitzpatrick, 1994).

\section{BRITTLE ICE ZONE AGE}

Figure 5 displays observed BIZ top and bottom ages from published age scales developed for the 18 drill sites discussed above (detailed ages in Tables 1-3). At deep icecore sites where snow accumulation rates are relatively high (e.g. GIS and inland WAIS sites), the age of ice within the BIZ is relatively young, dating from as few as 2 ka BP (Dye-3; Langway and others, 1985) to $9.5 \mathrm{ka} \mathrm{BP}$ (Byrd Station; Blunier and Brook, 2001). These ages represent $\sim 10 \%$ or less of the age of dated ice-core records developed from these sites. While the Holocene marks the beginning of relatively stable global climate, with the exception of the $8.2 \mathrm{ka}$ BP event (e.g. Alley and others, 1997), continued emphasis on understanding natural climate variability precludes classifying ice of this age as scientifically less interesting than older transitional and glacial ice (e.g. Mayewski and others, 2004; Marcott and others, 2013; Steig and others, 2013).

A wide range of ice ages is found within the BIZ at deep ice-core sites with low snow accumulation rates (e.g. EAIS plateau sites: Taylor Dome, Vostok, Dome C, Dronning Maud Land, Dome Fuji, Talos Dome), and intermediatedepth ice-core sites with higher snow accumulation rates (e.g. coastal Antarctic sites: Siple Dome, Berkner Island, Roosevelt Island, Law Dome). In intermediate-depth icecore records (all at intermediate ice-thickness coastal Antarctic locations), ice at the top of the BIZ dates to between approximately $4 \mathrm{ka} \mathrm{BP}$ at Roosevelt Island (personal communication from N. Bertler, 2013) and 9 ka BP at Law Dome (Morgan and others, 1997). Ice at these coastal Antarctic sites remains brittle to the bed, dating to a minimum of $\sim 40$ ka BP (Roosevelt Island; personal communication from N. Bertler, 2013) and in all cases placing at least $90 \%$ of the dated ice-core record within the BIZ. Brittle ice at EPICA Dome C dates from 29 to $80.5 \mathrm{ka} \mathrm{BP} \mathrm{(EPICA}$ Community Members, 2004). While not a large fraction of the entire ice-core record ( $\sim 6 \%$ of the $800 \mathrm{ka}$ record), this section of the Dome $\mathrm{C}$ ice core is highly detailed when compared to deeper ice where ice-flow thinning impairs resolution at this extremely low-accumulation site. From the surface to $\sim 2000 \mathrm{~m}$ depth, $55 \mathrm{~cm}$ long sections of the Dome $C$ ice core exhibit temporal resolution of 50-100 years or less, while below $2000 \mathrm{~m}$ similar sections contain 200-1000 years or more (Pol and others, 2010). Taylor Dome, a very shallow site, became brittle from a depth of $335 \mathrm{~m}$, dated to $10 \mathrm{kaBP}$, remaining brittle to the bed and spanning ice ages in excess of $160 \mathrm{ka}$ BP (Steig and others, 2000). Ice within the $\mathrm{BIZ}$ at these coastal Antarctic and EAIS plateau sites spans ages of fundamental interest to paleoclimate research, relevant to investigations into regional timing of the onset of deglaciation during the late-Pleistocene and rapid climate anomalies occurring during this transition (e.g. Younger Dryas, Antarctic Cold Reversal; Alley and others, 1993; WAIS Divide Project Members, 2013).

\section{MITIGATING BRITTLE ICE IMPACTS Drilling techniques}

Currently, drilling through the BIZ produces ice-core sections with several to many breaks, fractures and hairline cracks, commonly affecting more than half of recovered ice in the middle of this zone. Drilling fluid required at these depths pervades all cracks and fractures, contaminating many chemical analyses. At WAIS Divide, where BIZ core quality was the best of any recent United States-led drilling project, $1 \mathrm{~m}$ long core sections from 900 to $1200 \mathrm{~m}$ were on 
average between 'good' (containing zero to three breaks or $50 \%$ unfractured) and 'fair' quality (containing $>10 \mathrm{~cm}$ of core length without fractures; Souney and others, 2014).

As the only step performed at in situ pressures within the ice sheet (minimum of 2.0 MPa, maximum $12.4 \mathrm{MPa}$ in the $\mathrm{BIZ}$ ), with the added benefit of damping effects associated with a liquid-filled borehole, the drilling process provides important opportunities to reduce the major component of brittle fracture in ice cores by performing mechanically severe steps that might damage cores if performed at surface pressures $(\sim 700 \mathrm{hPa}, 0.07 \mathrm{MPa})$. For example, drilling at WAIS Divide employed a unique strategy specifically for brittle ice, performing three core breaks per $\sim 2.5 \mathrm{~m}$ drill run before returning the drill sonde to the surface (detailed in Souney and others, 2014). This technique of performing several core breaks per run at in situ pressure results in icecore sections that are ready to ship, without subjecting brittle ice cores at surface pressure to the vibration and high stresses of making circular-saw section cuts. A similar downhole technical innovation suggested by Ueda (2002) is the development of a drill sonde that captures and seals cores in a vessel at in situ pressures, potentially allowing for a more gradual transition to atmospheric pressure than the usual minutes-to-hours-long transition as the drill sonde is brought to the surface. Slowing the pressure and temperature transition by hoisting brittle ice-drill runs slowly to the surface, reducing drill penetration rate and considering drill fluid pressure balance have also been proposed (see the discussion by J. Schwander and others in IPICS, 2005).

Maintaining temperatures within drilling and on-site storage structures similar to those at depth in the borehole is a commonly practised technique in ice drilling (e.g. Souney and others, 2014). At Roosevelt Island, an actively cooled storage cave kept ice at $-23^{\circ} \mathrm{C}$ despite surface temperatures reaching as much as $-5^{\circ} \mathrm{C}$ (personal communication from D. Mandeno, 2014). Temperature gradients may reach several tens of degrees between in situ ice temperature and surface drill structure temperatures, which will cause differential heating of ice cores brought to the surface, inducing temperature and stress gradients as the ice-core surface warms (and expands) more quickly than the interior. However, it is difficult to overstate the primary impact of the pressure gradient between the BIZ and the surface, which, as a ratio, is a minimum of $30: 1$ at the shallowest observed BIZ onset (Vostok: 2.0 MPa at $250 \mathrm{~m}$, $\sim 0.07 \mathrm{MPa}$ surface air pressure) and grows to more than a $100: 1$ ratio at most ice-core drill sites (reaching a maximum BIZ bottom-to-surface-pressure ratio of $177: 1$ at the bottom of the Greenland Ice Sheet Project 2 (GISP2) BIZ: $1400 \mathrm{~m}$ depth, 12.4 MPa).

\section{Transport techniques}

Reduction of mechanical shock during core transport from the drill site to laboratories has been achieved primarily by sheathing brittle ice cores in tight-fitting nylon netting immediately upon removal from the drill, and delaying shipment of brittle ice for as long as logistically possible to allow for maximum relaxation. Use of netting was innovated at Berkner Island (Mulvaney and others, 2007), and the same was used successfully at WAIS Divide (Souney and others, 2014) and Roosevelt Island (personal communication from N. Bertler, 2013). While itself not preventing initial fracture of brittle ice cores, nylon netting holds badly fragmented sections in place, preventing any loss of stratigraphic order, and protects cores from further damage due to vibration during shipment.

Relaxation of ice cores after drilling is examined thoroughly by Gow (1971), measuring significant postdrilling volume expansion (density reduction) at all depths in the Byrd Station ice core. Cores from the BIZ around $800 \mathrm{~m}$ depth exhibit greatest expansion: $\sim 0.2 \%\left(0.002 \mathrm{~kg} \mathrm{~m}^{-3}\right.$ density decrease) after 8 months, $\sim 0.4 \%\left(0.004 \mathrm{~kg} \mathrm{~m}^{-3}\right.$ decrease) after 16 months, and up to $\sim 0.6 \%\left(0.006 \mathrm{~kg} \mathrm{~m}^{-3}\right.$ decrease) after 27 months (see fig. 2 of Gow, 1971). Cores from other depths expanded by an average of $\sim 0.2 \%$ $\left(0.002 \mathrm{~kg} \mathrm{~m}^{-3}\right.$ decrease) after 27 months. Nearly identical relaxation characteristics were observed in the GISP2 ice core (Gow and others, 1997). Ice cores retrieved using a hotwater drill at Siple Dome relaxed very quickly, likely due to the thermal drilling technique, but cores were also stored at relatively high surface temperatures after drilling (Engelhardt and others, 2000; Gow and Meese, 2007). Ice cores retrieved by PICO (Polar Ice Coring Office) mechanical drilling at Siple Dome showed very little relaxation, and remain brittle to date (Gow and Meese, 2007; personal communication from M. Twickler, 2013).

Much of this relaxation in brittle ice is attributed to slow dilation of highly pressurized bubbles abundant in this zone. This lends support to the practice of overwintering brittle ice, most recently performed at WAIS Divide (Souney and others, 2014). At Roosevelt Island, $\sim 2 \mathrm{~m}$ long drill runs were sheathed in netting and stored in a refrigerated snow cave for up to 14 days before making $1 \mathrm{~m}$ section cuts for shipment. Improvements were noted in bandsaw cuts after even this short period of relaxation, although some propensity for fracturing remained (personal communication from N. Bertler, 2013). It is important to note that overwintering or long-term storage of brittle ice cores delays sampling and analysis of this section of ice. While this delay is less significant on the time frame of a multi-year deep drilling project, for smaller endeavors, especially at intermediate-depth coastal sites where a significant portion of the dated ice-core record lies within the BIZ, delaying shipment and/or sampling of ice cores is more challenging.

\section{Sampling techniques}

Ice-core sampling is commonly performed at -20 to $-25^{\circ} \mathrm{C}$, making preliminary longitudinal cuts using a horizontal bandsaw and subsequent sampling with common vertical bandsaws. While a simple tool, the bandsaw applies consistent force at the cutting teeth, especially if tracking of the saw along-core is automated to steadily move the saw blade through the ice. After sufficient relaxation - allowing for slow dilation of air bubbles long after initial violent cracking and fracturing observed immediately after drilling brittle ice may feed through a bandsaw with little additional fracturing. Brittle ice below depths of $475 \mathrm{~m}$ from Roosevelt Island proved prohibitively brittle after 6 months stored at $-30^{\circ} \mathrm{C}$, with several instances of near-catastrophic fracturing during horizontal cutting due to vibration from the saw blade. At this depth, a conventional vertical bandsaw used to make $\sim 0.035 \mathrm{~m} \times 0.035 \mathrm{~m} \times 1.0 \mathrm{~m}$ rods of ice also began to add many fractures to previously flawless ice-core samples, which had immediately prior been cut into $\sim 0.1 \mathrm{~m} \times 0.035 \mathrm{~m} \times 1.0 \mathrm{~m}$ slabs without damage. Core sampling was halted at $500 \mathrm{~m}$ and the remaining ice stored at $-18^{\circ} \mathrm{C}$ for an additional year, after which cutting proceeded without significant challenges. 
Other cutting instruments may prove more conducive to processing brittle ice-core samples. Tison (1994) describes the use of a diamond-wire saw for preparing thin sections of debris-rich or brittle ice, an option attractive for its reduced vibration levels. However, with slow cutting rates and the high cost of diamond wires, this option may require significant development before being applicable to highvolume ice-core sample processing.

\section{Analytical techniques}

Many analyses performed in polar ice-core studies depend on relatively unbroken samples to prevent contaminants from altering original paleoclimate or paleo-environmental signals. Measurements of atmospheric gases preserved in bubbles ideally require avoidance of section cuts and other breaks present in ice-core samples, in order to exclude modern atmospheric gases from analysis. Major-ion and trace chemistry, analyzed in longitudinal samples from the center of ice cores in order to avoid modern contaminants imparted during drilling, shipment and sampling, requires removal of outer sample surfaces and cleaning of any exposed surfaces including section cuts and fractures. Drilling fluid pervades all fractures in ice-core samples especially fluids with low volatility, such as Estisol-240 (Dow Haltermann, Germany) coconut oil extract used at NEEM (North Greenland Eemian Ice Drilling) and Roosevelt Island - rendering chemical analyses extremely difficult, especially in ice from the BIZ.

Continuous-flow analysis (CFA) systems gravity-feed longitudinal ice samples through a sectioned heating plate, pumping meltwater directly into online instruments and/or fraction collectors to create discrete sub-samples (e.g. Osterberg and others, 2006; Bigler and others, 2011). When analyzing highly fractured samples in CFA systems, contamination affects not only fractured core sections, but also subsequent ice as relatively high-concentration contaminants wash out of sample lines and instruments. Additionally, vertical guide systems for gravity-feeding samples struggle to accommodate ice samples containing fractures, especially high-angle longitudinal fractures, which commonly wedge against plastic guides, disrupting sample flow and accurate depth logging.

Fractured sample sections are commonly removed entirely from CFA campaigns, such that CFA for majorion chemistry of brittle ice from the WAIS Divide ice core only processed $\sim 62 \%$ of ice from the depths of $577 \mathrm{~m}$ to $1300 \mathrm{~m}$ (personal communication from D. Ferris, 2014). An optical drill fluid detection system identified 27 instances of drill fluid contamination in CFA tubing while analyzing $175 \mathrm{~m}$ of brittle ice from the NEEM ice core (Warming and others, 2013). Using this detection system, particular negative impacts were noted for dust, conductivity, ammonium, hydrogen peroxide and sulfate datasets in brittle ice from the NEEM ice core. While technically challenging, feasible solutions have been developed for analyzing brittle ice-core samples with little sample loss, such as the high-resolution CFA water stable-isotope analysis of $13 \mathrm{~mm} \times 13 \mathrm{~mm} \times 1.0 \mathrm{~m}$ rods of ice from the WAIS Divide ice core (B. Vaughn and others, unpublished information). This approach used tightly fitting square acrylic tubes to protect the fragile ice rods during shipment, and also support them vertically in a sample rack during analysis - while light vibration successfully prevented wedging against the acrylic tubing during melting, even in highly fractured brittle ice (personal communication from B. Vaughn, 2014).

\section{CONCLUSION}

At 18 intermediate-depth and deep polar ice-core drilling sites across the Greenland ice sheet and West and East Antarctic ice sheets, the BIZ of poor-quality, highly fractured ice cores extends from a mean top depth of $545 \pm 162 \mathrm{~m}$ to a mean bottom depth of $1132 \pm 178 \mathrm{~m}$ (excluding intermediate-depth sites where the ice/bed interface is reached before the transition to ductile ice).

Firn-column thickness, controlled primarily by site temperature and snow accumulation rate, determines the precise overburden pressure at depth, quantified here to demonstrate that thicker (thinner) firn columns apply less (more) pressure at depth. Both reported BIZ top and bottom depths at GIS and WAIS sites are in fact deeper where FIT depth is similarly deep, as could be expected due to fluctuating overburden pressure; however, the deepening of the BIZ is greater than can be explained from overburden pressure alone. Additionally, the absence of this relationship at extremely cold, dry EAIS plateau sites suggests that other factors associated with firn densification and grain growth, affecting eventual clathrate formation and stability, are likely involved. While it is expected, due to pressure and temperature controls on clathrate stability, that the BIZ should transition to ductile, bubble-free ice at lower pressures (shallower depths) when ice temperatures are lower, this is not a quantitative feature of reported BIZ bottom depths including all deep drill sites. Although shallower stability of clathrates and shallower disappearance of air bubbles is observed in ice cores from colder sites, BIZ bottom depths do not clearly behave similarly. This is likely due to imprecision in reported BIZ depths, as well as the convolution of ice-core fracture caused purely by physical properties during relaxation and fracture due to additional stresses induced during retrieval (e.g. drill performance, handling techniques).

Consideration of this $531 \pm 138 \mathrm{~m}$ thick zone (mean BIZ top minus bottom depth excluding intermediate-depth sites), where pressurized air bubbles and ice relaxation upon retrieval of cores cause extensive and sometimes explosive fracturing, is pertinent to all projects developing records from ice cores recovered at depths greater than $\sim 400 \mathrm{~m}$ (i.e. mean BIZ top depth, $545 \mathrm{~m}$, less one standard deviation, $162 \mathrm{~m}$, gives $383 \mathrm{~m}$ ). Relatively high snow accumulation rates and thick ice ensure that ice from the BIZ at inland GIS and WAIS sites is restricted to Holocene ages, and spans $<10 \%$ of the completed ice-core records. EAIS plateau and coastal Antarctic drill sites, however, place a considerably larger amount of dated ice-core records in the BIZ. Low snow accumulation rates and large ice thicknesses at EAIS plateau sites place 20000-50000 years of glacial ice from these ice-core records in the $\mathrm{BIZ}$, affecting the resolution of these valuable records which are already challenged by low snow accumulation rates. Conversely, high snow accumulation rates and limited ice thickness at coastal Antarctic drill sites place the majority of recovered ice and dated icecore records within the $\mathrm{BIZ}$, at least $90 \%$ of the records at all coastal Antarctic drill sites.

Innovative drilling and transport strategies have had recent successes in minimizing fracturing in ice cores from the BIZ, including the WAIS Divide brittle-ice drilling 
technique, netting core after removing from the drill, and relaxing ice prior to shipment and/or sampling. However, comparatively little has been done to develop better sampling methods and techniques for analyzing highly fractured ice-core samples. Consideration of mitigating strategies at any stage can have beneficial impacts on downstream work phases, most importantly potentially improving final scientific results. Targeting of ice-core sites is increasingly focused by refined scientific questions, specific research interests and desire to infill areas of sparse geographical coverage. Advancing understanding of the physical mechanisms controlling the BIZ has the potential to significantly improve the continuous recovery and development of ice-core paleoclimate and environmental records, as this zone affects samples of ages spanning periods of fundamental scientific interest at many potential drill sites.

\section{ACKNOWLEDGEMENTS}

The author thanks R. Dadic and N. Bertler for thoughtful discussion of the manuscript. Thorough critique, discussion and encouragement from two anonymous reviewers significantly improved on the original text. The online University of Washington FirnMICE model (http://firny.ess.washington. edu/communityfirnmodel/) was used to model firn density and estimate overburden pressures. The author has been funded by the New Zealand Ministry of Business, Innovation, and Employment Grants (RDF-VUW-1103, CO5X0202), Victoria University and GNS Science. This work is a contribution to the Roosevelt Island Climate Evolution (RICE) Programme, funded by national contributions from New Zealand, Australia, Denmark, Germany, Italy, the People's Republic of China, Sweden, United Kingdom and the United States of America. The main logistic support for RICE was provided by Antarctica New Zealand (K049) and the US Antarctic Program (I-209M).

\section{REFERENCES}

Alley RB and 10 others (1993) Abrupt increase in Greenland snow accumulation at the end of the Younger Dryas event. Nature, 362(6420), 527-529 (doi: 10.1038/362527a0)

Alley RB, Mayewski PA, Sowers T, Stuiver M, Taylor KC and Clark PU (1997) Holocene climatic instability: a prominent, widespread event $8200 \mathrm{yr}$ ago. Geology, 25(6), 483-486 (doi: 10.1130/0091-7613(1997)025<0483:HCIAPW>2.3.CO;2)

Bigler M, Svensson A, Kettner E, Vallelonga P, Nielsen ME and Steffensen JP (2011) Optimization of high-resolution continuous flow analysis for transient climate signals in ice cores. Environ. Sci. Technol., 45(10), 4483-4489 (doi: 10.1021/es200118j)

Blunier T and Brook EJ (2001) Timing of millennial-scale climate change in Antarctica and Greenland during the last glacial period. Science, 291(5501), 109-112 (doi: 10.1126/science. 291.5501.109)

Brook E and 6 others (2005) Timing of millennial-scale climate change at Siple Dome, West Antarctica, during the last glacial period. Quat. Sci. Rev., 24(12-13), 1333-1343 (doi: 10.1016/j. quascirev.2005.02.002)

Brook EJ, Wolff E, Dahl-Jensen D, Fischer H and Steig EJ (2006) The future of ice coring: International Partnerships in Ice Core Sciences (IPICS). PAGES News, 14(1), 6-10

Buizert $C$ and 25 others (2012) Gas transport in firn: multiple-tracer characterisation and model intercomparison for NEEM, Northern Greenland. Atmos. Chem. Phys., 12(9), 4259-4277 (doi: 10.5194/acp-12-4259-2012)

Butkovich TR (1954) Ultimate strength of ice. SIPRE Res. Pap. 11
Cuffey KM and Clow G (2014) Temperature profile of the West Antarctic Ice Sheet Divide deep borehole. National Snow and Ice Data Center, Boulder, CO http://dx.doi.org/10.7265/N5V69GJW

Cuffey KM and Paterson WSB (2010) The physics of glaciers, 4th edn. Butterworth-Heinemann, Oxford

Dahl-Jensen D, Gundestrup N, Gogineni SP and Miller H (2003) Basal melt at NorthGRIP modeled from borehole, ice-core and radio-echo sounder observations. Ann. Glaciol., 37, 207-212 (doi: 10.3189/172756403781815492)

Dansgaard W, Johnsen SJ, Møller J and Langway CC Jr (1969) One thousand centuries of climatic record from Camp Century on the Greenland ice sheet. Science, 166(3903), 377-381

Dansgaard W and 10 others (1993) Evidence for general instability of past climate from a 250-kyr ice-core record. Nature, 364(6434), 218-220 (doi: 10.1038/364218a0)

Drinkwater MR, Long DG and Bingham AW (2001) Greenland snow accumulation estimates from satellite radar scatterometer data. J. Geophys. Res., 106(D24), 33 935-33950 (doi: 10.1029/ 2001JD900107)

Engelhardt H, Kamb B and Bolsey R (2000) A hot-water ice-coring drill. J. Glaciol., 46(153), 341-345 (doi: 10.3189/ 172756500781832873)

EPICA Community Members (2004) Eight glacial cycles from an Antarctic ice core. Nature, 429(6992), 623-628 (doi: 10.1038/ nature02599)

EPICA Community Members (2010) Stable oxygen isotopes of ice core EDML. http://doi.pangaea.de/10.1594/PANGAEA.754444

Etheridge DM, Steele LP, Langenfelds RL, Francey RJ, Barnola JM and Morgan VI (1996) Natural and anthropogenic changes in atmospheric $\mathrm{CO}_{2}$ over the last 1000 years from air in Antarctic ice and firn. J. Geophys. Res., 101(D2), 4115-4128 (doi: 10.1029/95JD03410)

Fitzpatrick JJ (1994) Preliminary report on the physical and stratigraphic properties of the Taylor Dome ice core. Antarct. J. US, 29(5), 84-86

Fitzpatrick JJ and 9 others (in press) Physical properties of the WAIS Divide ice core. J. Glaciol., 60(224) (doi: 10.3189/ 2014JoG14J100)

Frezzotti M and 12 others (2004) Geophysical survey at Talos Dome, East Antarctica: the search for a new deep-drilling site. Ann. Glaciol., 39, 423-432 (doi: 10.3189/172756404781814591)

Fujii Y and 25 others (2002) Deep ice core drilling to $2503 \mathrm{~m}$ depth at Dome Fuji, Antarctica. Mem. Natl Inst. Polar Res., Special Issue 56, 103-116

Gerland S, Oerter H, Kipfstuhl J, Wilhelms F, Miller $\mathrm{H}$ and Miners WD (1999) Density log of a $181 \mathrm{~m}$ long ice core from Berkner Island, Antarctica. Ann. Glaciol., 29, 215-219 (doi: 10.3189/ 172756499781821427)

Gow AJ (1968) Bubbles and bubble pressures in Antarctic glacier ice. J. Glaciol., 7(50), 167-182

Gow AJ (1971) Relaxation of ice in deep drill cores from Antarctica. J. Geophys. Res., 76(11), 2533-2541 (doi: 10.1029/ JB076i011p02533)

Gow AJ and Meese DA (2007) Physical properties, crystalline textures and $\mathrm{C}$-axis fabrics of the Siple Dome (Antarctica) ice core. J. Glaciol., 53(183), 573-584 (doi: 10.3189/ $002214307784409252)$

Gow AJ, Ueda HT and Garfield DE (1968) Antarctic ice sheet: preliminary results of first core hole to bedrock. Science, 161(3845), 1011-1013 (doi: 10.1126/science.161.3845.1011)

Gow AJ and 6 others (1997) Physical and structural properties of the Greenland Ice Sheet Project 2 ice core: a review. J. Geophys. Res., 102(C12), 26 559-26575 (doi: 10.1029/97JC00165)

The Greenland Summit Ice Cores CD-ROM (1997) Available from National Snow and Ice Data Center, University of Colorado/ World Data Center-A for Paleoclimatology, National Geophysical Data Center, Boulder, CO http://www.ncdc.noaa.gov/ paleo/icecore/greenland/summit/index.html

Gundestrup NS and Hansen BL (1984) Bore-hole survey at Dye-3, south Greenland. J. Glaciol., 30(106), 282-288 
Herron MM and Langway CC Jr (1980) Firn densification: an empirical model. J. Glaciol., 25(93), 373-385

Hondoh T and 15 others (1999) Basic analyses of Dome Fuji deep ice core. Part 2: physical properties. Polar Meteorol. Glaciol., 13, 90-98

Hörhold MW, Kipfstuhl S, Wilhelms F, Freitag J and Frenzel A (2011) The densification of layered polar firn. J. Geophys. Res., 116(F1), F01001 (doi: 10.1029/2009JF001630)

Ikeda-Fukazawa T, Hondoh T, Fukumura T, Fukazawa $\mathrm{H}$ and Mae $\mathrm{S}$ (2001) Variation in $\mathrm{N}_{2} / \mathrm{O}_{2}$ ratio of occluded air in Dome Fuji antarctic ice. J. Geophys. Res., 106(D16), 17 799-17810 (doi: 10.1029/2000JD000104)

International Partnerships in Ice Core Sciences (IPICS) (2005) IPICS 2004 Workshop Report, 13-16 March 2004, Algonkian Regional Park, Sterling, VA http://www.icedrill.org/documents/ view.shtml?id=38

Jouzel J (2013) A brief history of ice core science over the last $50 \mathrm{yr}$. Clim. Past, 9(6), 2525-2547 (doi: 10.5194/cp-9-2525-2013)

Kawamura K and 17 others (2007) Northern Hemisphere forcing of climatic cycles in Antarctica over the past 360,000 years. Nature, 448(7156), 912-916 (doi: 10.1038/nature06015)

Kipfstuhl S, Pauer F, Kuhs WF and Shoji H (2001) Air bubbles and clathrate hydrates in the transition zone of the NGRIP deep ice core. Geophys. Res. Lett., 28(4), 591-594 (doi: 10.1029/ 1999GL006094)

Kovacs A, Weeks WF and Michitti F (1969) Variation of some mechanical properties of polar snow, Camp Century, Greenland. CRREL Res. Rep. 276

Kreutz K, Koffman B, Breton D and Hamilton G (2011) Microparticle, conductivity, and density measurements from the WAIS Divide deep ice core, Antarctica. National Snow and Ice Data Center, Boulder, CO http://dx.doi.org/10.7265/N5K07264

Kuhs WF, Klapproth A and Chazallon B (2000) Chemical physics of air clathrate hydrates. In Hondoh T ed. Physics of ice core records. Hokkaido University Press, Sapporo, 373-392

Langway CC Jr, Oeschger H and Dansgaard W eds. (1985) Greenland ice core: geophysics, geochemistry, and the environment. (Geophysical Monograph 33) American Geophysical Union, Washington, DC

Ligtenberg SRM, Helsen MM and Van den Broeke MR (2011) An improved semi-empirical model for the densification of Antarctic firn. Cryosphere, 5(4), 809-819 (doi: 10.5194/tc-5-809-2011)

Lipenkov VYa (2000) Air bubbles and air-hydrate crystals in the Vostok ice core. In Hondoh T ed. Physics of ice core records. Hokkaido University Press, Sapporo, 327-358

Marcott SA, Shakun JD, Clark PU and Mix AC (2013) A reconstruction of regional and global temperature for the past 11,300 years. Science, 339(6124), 1198-1201 (doi: 10.1126/science.1228026)

Martinerie P and 8 others (2009) Long-lived halocarbon trends and budgets from atmospheric chemistry modelling constrained with measurements in polar firn. Atmos. Chem. Phys., 9(12), 3911-3934 (doi: 10.5194/acp-9-3911-2009)

Mayewski PA and 15 others (2004) Holocene climate variability. Quat. Res., 62(3), 243-255 (doi: 10.1016/j.yqres.2004.07.001)

Miller SL (1969) Clathrate hydrates of air in Antarctic ice. Science, 165(3892), 489-490 (doi: 10.1126/science.165.3892.489)

Morgan V, Wehrle E, Fleming A, Richardson M, Elcheikh A and Brand R (1994) Technical aspects of deep ice drilling on Law Dome. Mem. Natl Inst. Polar Res., Special Issue 49, 78-86

Morgan VI, Wookey CW, Li J, Van Ommen TD, Skinner W and Fitzpatrick MF (1997) Site information and initial results from deep ice drilling on Law Dome, Antarctica. J. Glaciol., 43(143), 3-10

Morse DL and 7 others (1999) Accumulation rate measurements at Taylor Dome, East Antarctica: techniques and strategies for mass balance measurements in polar environments. Geogr. Ann. A, 81(4), 683-694

Motoyama H (2007) The second deep ice coring project at Dome Fuji, Antarctica. Sci. Drilling, 5(5), 41-43 (doi: 10.22.04/iodp. sd.5.05.2007)
Mulvaney R, Alemany O and Possenti P (2007) The Berkner Island (Antarctica) ice-core drilling project. Ann. Glaciol., 47, 115-124 (doi: 10.3189/172756407786857758)

NEEM Community Members (2013) Eemian interglacial reconstructed from a Greenland folded ice core. Nature, 493(7433), 489-494 (doi: 10.1038/nature11789)

Oerter H, Graf W, Meyer H and Wilhelms F (2004) The EPICA ice core from Dronning Maud Land: first results from stable-isotope measurements. Ann. Glaciol., 39, 307-312 (doi: 10.3189/ 172756404781814032)

Osterberg EC, Handley MJ, Sneed SB, Mayewski PA and Kreutz KJ (2006) Continuous ice core melter system with discrete sampling for major ion, trace element, and stable isotope analyses. Environ. Sci. Technol., 40(10), 3355-3361 (doi: 10.1021/ es052536w)

Parrenin F and 26 others (2007) The EDC3 chronology for the EPICA Dome C ice core. Climate Past, 3(3), 485-497 (doi: 10.5194/cp-3-485-2007)

Parrenin F and 12 others (2012) Volcanic synchronisation between the EPICA Dome C and Vostok ice cores (Antarctica) 0-145 kyr BP. Climate Past, 8(3), 1031-1045 (doi: 10.5194/cp-81031-2012)

Pauer F, Kipfstuhl J and Kuhs WF (1995) Raman spectroscopic study on the nitrogen/oxygen ratio in natural ice clathrates in the GRIP ice core. Geophys. Res. Lett., 22(8), 969-971 (doi: 10.1029/95GL00705)

Petit JR and 18 others (1999) Climate and atmospheric history of the past 420,000 years from the Vostok ice core, Antarctica. Nature, 399(6735), 429-436 (doi: 10.1038/20859)

Petrovich JJ (2003) Mechanical properties of ice and snow. J. Mater. Sci., 38(1), 1-6 (doi: 10.1023/A:1021134128038)

Pol K and 12 others (2010) New MIS 19 EPICA Dome C high resolution deuterium data: hints for a problematic preservation of climate variability at sub-millennial scale in the 'oldest ice'. Earth Planet. Sci. Lett., 298(1-2), 95-103 (doi: 10.1016/j. epsl.2010.07.030)

Rasmussen SO and 23 others (2013) A first chronology for the North Greenland Eemian Ice Drilling (NEEM) ice core. Climate Past, 9(6), 2713-2730 (doi: 10.5194/cp-9-2713-2013)

Salamatin AN, Lipenkov VY and Blinov KV (1994) Vostok (Antarctica) climate record time-scale deduced from the analysis of a borehole-temperature profile. Ann. Glaciol., 20, 207-214

Schilt $A$ and 10 others (2010) Atmospheric nitrous oxide during the last 140,000 years. Earth Planet. Sci. Lett., 300(1-2), 33-43 (doi: 10.1016/j.epsl.2010.09.027)

Schwander J and 6 others (1993) The age of the air in the firn and ice at Summit, Greenland. J. Geophys. Res., 98(D2), 2831-2838 (doi: 10.1029/92JD02383)

Severi M and 13 others (2007) Synchronisation of the EDML and EDC ice cores for the last $52 \mathrm{kyr}$ by volcanic signature matching. Climate Past, 3(3), 367-374 (doi: 10.5194/cp-3-367-2007)

Shoji $\mathrm{H}$ and Langway CC Jr (1982) Air hydrate inclusions in fresh ice core. Nature, 298(5874), 548-550 (doi: 10.1038/298548a0)

Shoji $\mathrm{H}$ and Langway CC Jr (1987) Microscopic observations of the air hydrate-bubble transformation process in glacier ice. J. Phys. IV [Paris], 48(Colloq. C1), Supplément au 3, 551-556

Souney J and 15 others (2014) Core handling and processing for the WAIS Divide ice-core project. Ann. Glaciol., 55(68) (doi: 10.3189/2014AoG68A008) (see paper in this issue)

Steig EJ and 7 others (2000) Wisconsinan and Holocene climate history from an ice core at Taylor Dome, western Ross Embayment, Antarctica. Geogr. Ann. A, 82(2-3), 213-235 (doi: 10.1111/j.0435-3676.2000.00122.x)

Steig EJ and 21 others (2013) Recent climate and ice-sheet changes in West Antarctica compared with the past 2,000 years. Nature Geosci., 6(5), 372-375 (doi: 10.1038/ngeo1778)

Stenni B and 39 others (2011) Expression of the bipolar see-saw in Antarctic climate records during the last deglaciation. Nature Geosci., 4(1), 46-49 (doi: 10.1038/ngeo1026) 
Timmermann R and 16 others (2010) A consistent data set of Antarctic ice sheet topography, cavity geometry, and global bathymetry. Earth Syst. Sci. Data, 2(2), 261-273 (doi: 10.5194/ essd-2-261-2010)

Tison J-L (1994) Diamond wire-saw cutting technique for investigating textures and fabrics of debris-laden ice and brittle ice. J. Glaciol., 40(135), 410-414

Uchida T, Duval P, Lipenkov VY, Hondoh T, Mae S and Shoji H (1994) Brittle zone and air-hydrate formation in polar ice sheets. Mem. Natl Inst. Polar Res. 49, Special Issue, 298-305

Ueda HT (2002) Some thoughts on deep core drilling systems design. Mem. Natl Inst. Polar Res., Special Issue 56, 117-125

Ueda HT and Garfield DE (1968) Drilling through the Greenland ice sheet. CRREL Spec. Rep. 126

Ueda $\mathrm{H}$ and Garfield DE (1969) Core drilling through the Antarctic ice sheet. CRREL Tech. Rep. 231

Ueltzhöffer KJ and 6 others (2010) Distribution of air bubbles in the EDML and EDC (Antarctica) ice cores, using a new method of automatic image analysis. J. Glaciol., 56(196), 339-348 (doi: 10.3189/002214310791968511)
Van Ommen TD, Morgan VI, Jacka TH, Woon S and Elcheikh A (1999) Near-surface temperatures in the Dome Summit South (Law Dome, East Antarctica) borehole. Ann. Glaciol., 29, 141-144 (doi: 10.3189/172756499781821382)

Vasiliev NI, Talalay P and Vostok Deep Ice Core Drilling Parties (2011) Twenty years of drilling the deepest hole in ice. Sci. Drilling, 11, 41-45 (doi: 10.2204/iodp.sd.11.05.2011)

Vinther BM and 12 others (2006) A synchronized dating of three Greenland ice cores throughout the Holocene. J. Geophys. Res., 111(D13), D13102 (doi: 10.1029/2005JD00692)

WAIS Divide Project Members (2013) Onset of deglacial warming in West Antarctica driven by local orbital forcing. Nature, 500(7463), 440-444 (doi: 10.1038/nature12376)

Warming E, Svensson A, Vallelonga P and Bigler M (2013) A technique for continuous detection of drill liquid in ice cores. J. Glaciol., 59(215), 503-506 (doi: 10.3189/2013JoG12J124)

Watanabe O, Kamiyama K, Motoyama H, Fujii Y, Shoji $\mathrm{H}$ and Satow K (1999) The palaeoclimate record in the ice core from Dome Fuji station, Antarctica. Ann. Glaciol., 29, 176-178 (doi: $10.3189 / 172756499781821553$ 